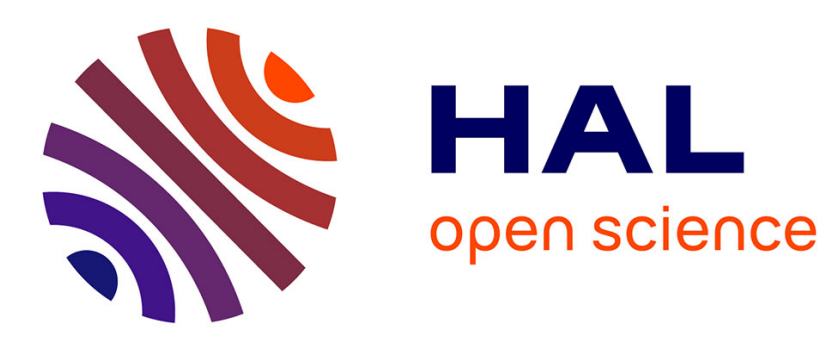

\title{
Fishermen's taverns: Public houses and maritime labour in an early modern French fishing community
}

\author{
Romain Grancher
}

\section{To cite this version:}

Romain Grancher. Fishermen's taverns: Public houses and maritime labour in an early modern French fishing community. International Journal of Maritime History, 2016, 28 (4), pp.671-685. hal-01888468

\section{HAL Id: hal-01888468 \\ https://hal.science/hal-01888468}

Submitted on 15 Oct 2018

HAL is a multi-disciplinary open access archive for the deposit and dissemination of scientific research documents, whether they are published or not. The documents may come from teaching and research institutions in France or abroad, or from public or private research centers.
L'archive ouverte pluridisciplinaire HAL, est destinée au dépôt et à la diffusion de documents scientifiques de niveau recherche, publiés ou non, émanant des établissements d'enseignement et de recherche français ou étrangers, des laboratoires publics ou privés. 
Fishermen's Taverns.

\title{
Public Houses and Maritime Labour in an Early Modern French Fishing Community
}

\author{
(Dieppe, Eighteenth century)*
}

Romain Grancher

Chargé de recherches CNRS

\section{TEMOS FRE 2015}

'Anyone dealing with popular culture will very soon come across public houses', the French historian Daniel Roche wrote in an article published 30 years ago. ${ }^{1}$ Starting from an observation which he had already made in his book Le Peuple de Paris, that 'the link between public houses and the transgression of norms is all too often overstated, when in fact they are a mere component of daily life', he recommended paying closer attention to the more mundane aspects of this institution, so central to Old Regime societies. ${ }^{2}$ In the wake of the research carried out by Maurice Agulhon on Provencal barrack rooms, Roche thus intended to locate his analysis of Paris's public houses within a cultural history of the forms and rituals of popular sociability in the eighteenth century. ${ }^{3}$ However, since he was attuned to all the social uses of these venues, Roche also highlighted in this article - albeit in passing - the wide range of economic, commercial and professional activities taking place within public houses and insisted in particular on the ways in which agents from the world of Parisian crafts made use of them. ${ }^{4}$ In other words, he identified public houses as a historical object of prime importance, and acted as a trailblazer by laying the foundations of an inquiry into the place and role of public houses in Old Regime France. Nonetheless, and in spite of the fact that Thomas Brennan's book Public Drinking and Popular Culture in Eighteenth-Century Paris (1988) has since confirmed and clarified the picture set out by Roche in the early 1980s, the world of public houses has hardly drawn the attention of French historians since then, and it is fair to claim that it now represents a blind spot in the historiography of modern France. ${ }^{5}$

This observation is all the more striking if one considers not only the past importance, but also the current vitality and ongoing renewal of this field of research in European historiography, notably in Germany and Britain. Among the most noteworthy contributions made by this literature about public houses in modern Europe, it is important to stress, first, the elaboration - beyond the various institutional and geographical situations - of a shared terminology. The generic term 'public house',

\footnotetext{
* I'm grateful to editors for their advice and comments, and also to Beat Kümin for reading a first draft of the text and providing me with references.

${ }^{1}$ Daniel Roche, 'Le cabaret parisien et les manières de vivre du peuple,' in Maurice Garden and Yves Lequin, eds., Habiter la ville. XVe-XXe siècles (Lyon, 1984), 233-251.

${ }^{2}$ Daniel Roche, Le peuple de Paris. Essai sur la culture populaire au XVIII siècle (Paris, 1998 [1981]), 339.

${ }^{3}$ Maurice Agulhon, La République au village. Les populations du Var de la Révolution à la Seconde République (Paris, 1970); Maurice Agulhon, 'Les chambrées en basse Provence : histoire et ethnologie,' Revue historique, No. 498 (1971), 337-368.

${ }^{4}$ Daniel Roche, 'Le cabaret parisien', 244.

${ }^{5}$ Thomas Brennan, Public Drinking and Popular Culture in Eighteenth-Century Paris (Princeton, 1988). See Daniel Roche's review of the book in Annales. Économies, Sociétés, Civilisations, 46, No. 3 (1991), 624-626. It must be noted, however, that in the wake of Thomas Brennan's research, a number of studies have brought important insights into modes and sites of consumption - of both food and alcohol - in the Old Regime. See, on the one hand, Mathieu Lecoutre, Ivresse et ivrognerie dans la France moderne (Rennes and Tours, 2011); and Didier Nourrisson, Crus et cuites: histoire du buveur (Paris, 2013); and, on the other hand, Rebecca Spang, The invention of restaurant: Paris and modern gastronomic culture (Cambridge and London, 2000); and Florent Quellier, Festins, ripailles et bonne chère au Grand Siècle (Paris, 2015).
} 
which refers to a private place which is open to the public, where everyone may come and consume alcohol, encompasses the very wide range of institutions found in the archives. In practice, their specific names vary according to their status and the range of services offered to their patrons. A distinction is usually made between three specific institutions: the alehouse, the tavern and the inn although admittedly sources do not always make it possibly to identify each establishment in such a formal way. ${ }^{6}$ Such a strong emphasis on the services on offer represents a second major gain from the research conducted successively by several generations of historians seeking a better understanding of the everyday functioning of these institutions which are key to modern societies. In contrast with the subversive, or even criminogenic image attached to public houses by public authorities which, everywhere, were concerned to see them proliferate, numerous studies have shed light on the many functions performed by alehouses, taverns and inns in Old Regime communities. ${ }^{7}$ These studies conclude that social actors did certainly not attend these establishments for the sole purposes of drinking, eating or finding accommodation. These were, undeniably, fundamental aspects, which should not be downplayed. However, to these basic services one must add far more specific uses which, if overlooked, preclude a full assessment of the importance of these institutions. In eighteenthcentury London, for instance, alehouses were patronised for a host of reasons: patrons came to drink, undoubtedly, but also attended to many other things there. ${ }^{8}$ As in Southampton, Paris or Bern in the same period, people also met there in order to exchange information, negotiate purchases and seal all sorts of deals. ${ }^{9}$ Public houses were social and entertainment venues which might also function as common rooms, where members of the community met to discuss current administrative issues, and sometimes even to address issues which bordered on the judiciary, such as the settlement of disagreements. ${ }^{10}$ Thus, in brief, number of works have therefore highlighted the fact that these semipublic institutions played a very specific role under the Old Regime, at the intersection of economics, politics and the law.

\footnotetext{
${ }^{6}$ This contribution uses the trio put forward in Beat Kümin and B. Ann Tlusty, 'Introduction', in Beat Kümin and B. Ann Tlusty, eds., The World of the Tavern. Public Houses in Early Modern Europe (Aldershot, 2002), 6-8: "Public house" thus serves as the umbrella term for all relevant establishments [...], while "publican" provides the general expression for all hosts. As for common subcategories, "inn" refers to a fully privileged house entitled to offer alcoholic drinks, hot food, accommodation, stables and catering for large parties, while "tavern" designates an establishment with more limited rights, selling mainly wine and cold food, but not normally providing hot meals or accommodation. "Ale"-, "beer"-, "brandy"- and "ginhouse" are used for outlets with similar restrictions, but specializing in particular drinks'. Regarding this, see also the very useful multilingual glossary assembled by Beat Kümin, Drinking Matters. Public Houses and Social Exchange in Early Modern Central Europe (Basingstoke and New York, 2007), XII.

${ }^{7}$ Classic statements include Alan Everitt, 'The English Urban Inn 1560-1760', in Alan Everitt, Perspectives in English urban history (Basingstoke and London, 1973), 91-137; Peter Clark, 'The Alehouse and the Alternative Society,' in Donald H. Pen and Keith Thomas, eds., Puritans and Revolutionaries: Essays in Seventeenth-Century History presented to Christopher Hill (Oxford, 1978), 47-72; Keith Wrightson, 'Alehouses, Order and Reformation in Rural England, 1590-1660', in Eileen Yeo and Stephen Yeo, eds., Popular Culture and Class Conflict 1590-1914: Exploration in the History of Labour and Leisure (Brighton, 1981), 1-27.

${ }^{8}$ John Chartres, 'The Eighteenth-Century English Inn: a Transient "Golden Age"?', in Kümin and Tlusty, The World of the Tavern, 205-226.

9 James R. Brown, 'The Landscape of Drink: Inns, Taverns and Alehouses in Early Modern Southampton' (Unpublished PhD thesis, University of Warwick, 2007), 113-173; Roche, 'Le cabaret parisien', 244; Beat Kümin, 'Useful to have, but difficult to govern. Inns and taverns in early modern Bern and Vaud', Journal of Early Modern History, 3, No. 2 (1999), 161-166.

${ }^{10}$ Everitt, 'The English Urban Inn', 110-113; Chartres, 'The Eighteenth-Century English Inn', 219-222. Regarding alehouse sociability, see in particular the recent book by Mark Hailwood, Alehouses and Good Fellowship in Early Modern England (Woodbridge, 2014).
} 
The present article, focusing on the social uses of public houses in Dieppe's fishing world in the eighteenth century, has two objectives. First, to shed new light on a research topic which has been largely ignored by French historiography. And also, secondly, to make a contribution to the inventory of the functions fulfilled by alehouses, taverns and inns in the modern age, approaching it from a specific angle: that of labour history - maritime labour, in this instance. The central role of public houses in coastal communities does not need to be proven, given how integral it is nowadays to the imaginary of ports. ${ }^{11}$ Nonetheless, the way in which maritime activities and public houses were connected in practice has never been studied per se and it is precisely the aim of this article to suggest that these interactions between the world of alehouses and the fishing world offer vast and largely uncharted research potential. In this perspective, I have used the analysis of civilian procedures brought to Dieppe's Admiralty Court in order to show how, within this world of labour, public houses performed both the role of centres for the organisation of fishing, and local social hubs where the reputations of the actors of the craft community were established, as well as the bonds between them. ${ }^{12}$

\section{Dieppe's Fishing Community in the Eighteenth Century}

This discussion is located within the context of Dieppe, a French port town of the Normandy coast of the Channel. Situated on the left bank of a deep valley dug by the river Arques at its mouth, Dieppe formed, with its right-bank suburb Le Pollet, a very important fishing port in eighteenth-century France. Fishermen and their families amounted to about 5,000 inhabitants out of 20,000, that is to say a quarter of the population according to the population sizes put forward by Noël de la Morinière in the late eighteenth century. ${ }^{13}$ However, fishing - the port's main activity - involved a much bigger proportion of community members - from shipowners and traders to the many participants involved in the fish trade, be they fishmongers or powerful wholesale merchants, for instance. And this does not include a wide array of peripheral jobs whose prosperity was largely dependent on fishing armaments, such as, for instance, corporations of carpenters, rope-makers and sail makers involved in building and repairing fishing boats and their apparatus, the local area's ploughmen, whose hemp production was used to make rigging and nets and, lastly, a wide variety of labour hands allocated to warehouse work or to preparing fish. Besides, the local fishermen population was not enough to

\footnotetext{
${ }^{11}$ The importance of public houses in maritime societies has already been emphasised by Alain Cabantous, Dix mille marins face à l'océan. Les populations maritimes de Dunkerque au Havre aux XVII' et XVIII' siècle (vers 1660-1794). Étude sociale (Paris, 1991), 331-333; Alain Cabantous, Les côtes barbares : pilleurs d'épaves et sociétés littorales en France (1680-1830) (Paris, 1993), 182-185. For the English-speaking world, much scattered information can be found in Marcus Rediker, Between the Devil and the Deep Blue Sea. Merchants -Seamen, Pirates and The Anglo-Maritime World, 1700-1750 (Cambridge, 1987); and in Nicholas A. M. Rodger, The Wooden world. An anatomy of the Georgian Navy (London, 1986).

${ }^{12}$ In Old Regime France, Admiralty Courts were special courts, specialising among other things in the settlement of maritime disputes. The analysis presented here is based on about 50 cases involving publicans, either as litigants or as witnesses. These cases were selected from a corpus of 400 civilian cases linked to fishing taken to Dieppe's Admiralty Court between 1720 and 1790. Regarding the construction of this corpus of judicial sources and, more generally, the functioning of Dieppe's Admiralty Court in the $18^{\text {th }}$ century, please refer to Romain Grancher, 'Les usages de la mer. Droit, travail et ressources dans un monde de la pêche (Dieppe, années 1720années 1820)' (Unpublished PhD thesis, University of Rouen, 2015), 93-148.

${ }^{13}$ This account is based on Guy Lemarchand, La fin du féodalisme dans le pays de Caux. Conjoncture économique et démographique et structure sociale dans une région de grande culture, de la crise du XVII siècle à la stabilisation de la Révolution (1640-1795) (Paris, 1989), II; Éric Dardel, État des pêches maritimes sur les côtes occidentales de la France au début du XVIII' siècle d'après les procès-verbaux de visite de l'Inspecteur des Pêches Le Masson du Parc (1723-1732) (Paris, 1941), 87; and Simon Barthélemy Joseph Noël de la Morinière, Premier essai sur le département de la Seine Inférieure, contenant les districts de Gournay, Neufchâtel, Dieppe et Cany (Rouen, 1795/an III), 195.
} 
complete the crews of the 150 or so ships fitted out every year in the port, requiring additional numbers from 'fishing labourers' - so great was this demand that the recruitment pool of Dieppe fisheries extended to the neighbouring rural parishes, within a radius of several dozen kilometres.

In the eighteenth century, the organisation of fishing followed a seasonal calendar known as Dieppe's 'Grand Métier' (the Great Labour). It was divided into four main periods, corresponding to the same number of fish species targeted and fishing techniques used. The highlight of the year was 'harengaison' (herring fishing), a twofold process. Indeed, a first season took place off the Yarmouth coast, in England, from September onward. Then, when herring shoals from the North Sea swam into the Channel, between October and December, a second season started, close to the Normandy coast. Like mackerel, which was a migrating species fished between May and July, herring was caught by using drift nets known as 'seines,' which were spread so as to catch the shoals of fish which got tangled up in the netting by following the tide. Between these two 'large catches,' herring and mackerel, which were mostly sold as salted fish, came two shorter seasons, during which fishermen normally focused on catching fresh fish, with other tools such as the dredge, a forerunner of the trawling net. Some, however, in the wake of the Le Pollet suburb fishermen, focused on 'fresh' fishing all year round, but used lines with hooks - a technique in which they were regarded as the best specialists.

Fig. 1. Simplified operational diagram of Dieppe's share system

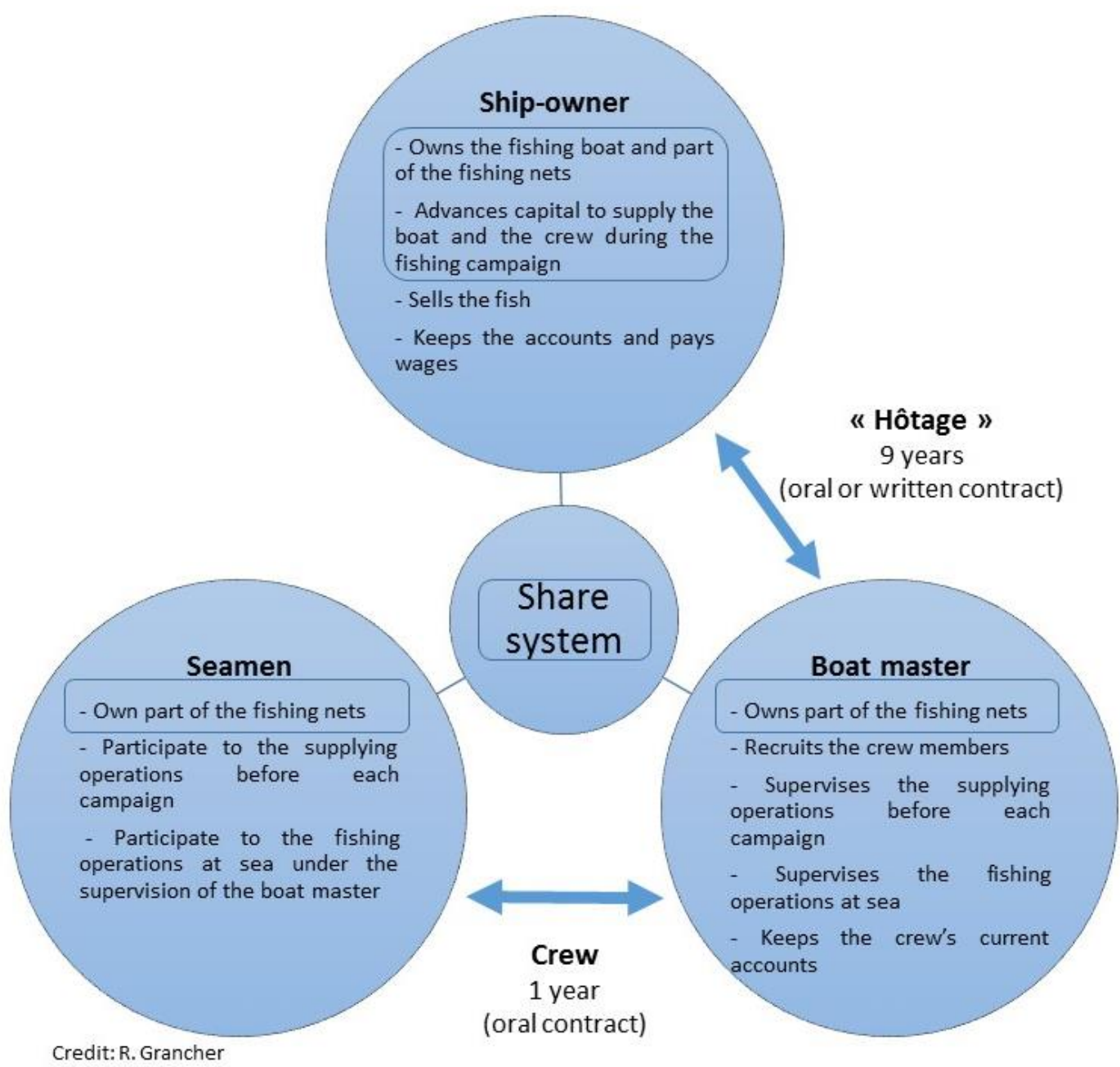

Whichever techniques are mobilised and resources are used, equipping a fishing boat relies on two social institutions: 'hôtage' and the share system. Hôtage was a contract-based relationship creating 
reciprocal duties between a ship-owner and a boat master. The latter committed for a nine-year period to recruit a crew before each fishing season in order to lead the host's boat 'out to sea'. This legal bond between master and ship-owner, materialized by the boat commissioned by the latter for the former, was part of a cluster of wider social and economic relationships: those created every year by these two actors with a crew of ordinary seamen, in the context of a partnership aimed at pooling the funds and tools required for all the fishing campaigns. Indeed, according to the jurisprudence of the Rouen Parliament, seamen (socii) and their masters (conductor) formed an 'indivisible body', akin to a 'society'. ${ }^{14}$ In Dieppe as in many fishing societies, the exact terms of this partnership were defined by the share system, whereby each member of the community was expected to contribute to the venture through their own capital and/or labour, in return for which they earned a profit which was proportional to their input. ${ }^{15}$ Bound by 'a kind of society contract', seamen, masters and ship-owners thus became partners in an association, sharing losses as well as profits. ${ }^{16}$

\title{
Public Houses and Fishing Organisation
}

After this overview of Dieppe's fishing organisation, the roles fulfilled by public houses in Dieppe's port at every stage of the fish production and commercialisation process must be examined. Alehouses, inns and taverns, clustered near the docks and in neighbouring streets, such as Dieppe's rue Prison, or Le Pollet's Grande Rue, functioned in interaction with the fishing world. The testimony below already suggests how, on various levels, the economy of a Dieppe inn might connect with that of ship armaments.

\begin{abstract}
Heard Maître Delagrave, the lawyer speaking for [René] Hablot, who proved that said Hablot, a seaman on [Jean] Boquet's crew, was fishing during the first week of Lent this year, became ill and had to go back on land, at Sir L'herbourg's, an innkeeper in this town, where the crew had its tab [...]. However, his illness became so violent that he could not be carried anywhere else than the inn of the aforementioned L'Herbourg, where he was put to bed and was so ill within seventeen days that he received the last rites; that in this illness he spent the little means that he had, which were an amount of 40 livres which was not enough to settle his spending in dressings, medicine and food, so that he found himself indebted to the aforementioned L'herbourg, for a sum of 21 livres, as a pledge for the aforementioned L'herbourg allegedly had the supplicant's nets brought to him, that were on board and are still withheld by the aforementioned L'herbourg. ${ }^{17}$
\end{abstract}

The reason why public houses were literally integrated into the fishing economy is, first, that Dieppe's fishing crews traditionally kept a 'tab' ('faire le commun') at an innkeeper's, with whom they made a sort of tacit partnership contract. When they were on land, before the season started, or just for a brief stop at the port, the master and his crew met daily in these venues, in order to eat and drink together, as attested by numerous procedures brought by publicans eager to have debts owed to them officially recognised. This was, for instance, the grounds on which Robert Guiche, an innkeeper, who hosted in his establishment the crew led by Master Augustin Fréchon, summoned the latter to

\footnotetext{
${ }^{14}$ Archives Nationales, Paris, $\mathrm{F}^{12}$ 1836, Arrêt du Parlement de Rouen, 14/02/1732. Regarding this 'arrêt', see Éric Dardel, La pêche harenguière en France : étude d'histoire économique et sociale (Paris, 1941), 82-92.

${ }^{15}$ In the vast bibliography dealing with the share system, see James M. Acheson, 'Anthropology of fishing', Annual Review of Anthropology, 10 (1981), 278-280; Yvan Breton, 'L'anthropologie sociale et les sociétés de pêcheurs. Réflexions sur la naissance d'un sous-champ disciplinaire', Anthropologie et Sociétés, 5, No. 1 (1981), 7-27; and, lastly, Rob van Ginkel, Braving Troubled Waters. Sea Change in a Dutch Fishing Community (Amsterdam, 2009), 170-183.

${ }^{16}$ Robert-Joseph Pothier, Supplément au traité du contrat de louage, ou Traité des contrats de louage maritime (Paris, 1765), 160.

${ }_{17}$ Archives Municipales de Dieppe (AMD henceforth), EE/8ter, Dossiers de procédures, 04/08/1733. My emphasis.
} 
an audience on 15 March 1735, in order to have him sentenced in solidarity with his seamen to settle a debt of 19 livres, accumulated 'over several days at his inn, while they worked on their boat to prepare it for the herring season'. ${ }^{18}$

A close look at the ledgers kept by ship-owner Nicolas Vasse, one of the richest ship-owners in the area in the first half of the eighteenth century, confirms that this practice existed, and was most likely applied all over Dieppe in this period. Indeed, it can be noticed that before each fishing season, during the few weeks preceding the departure for the sea which crew members dedicated to preparing their boat, Vasse wrote in the individual account of each master working under his 'hôtage' the amounts given as advances to them in order towards the ' $\mathrm{tab}^{\prime} .{ }^{19}$ The meals taken together in the establishment where the crew 'share their meal', funded directly by the partnership's money, thus represent a form of pay in kind for the fishermen when they are on land. ${ }^{20}$ It is known, moreover, that fishing labourers from the neighbouring countryside were in the habit of lodging at the inn where the 'tab' was based - as in the case of the above-mentioned René Hablot who, because of his poor health, had to stay in bed at the inn of publican L'herbourg during the spring of $1733 .{ }^{21}$ However, since he was from the village of Veules, he would normally stay at the same inn each time he left his village, which was a few hours' walk away, and board a ship in Dieppe. It was also the situation, for instance, of ordinary seaman Antoine Duhornay who, during an inquiry, also stated that he resided in the parish of Quiévremont, but was 'at present in the city of Dieppe, staying with sir Heurtel, an innkeeper'. ${ }^{22}$

Thus, in brief, each crew had their inn, where they had a shared account with credit facilities, which was comparable with the 'tabs' allowed, nowadays, to some regular customers in exchange for their assiduous consumption. ${ }^{23}$ This was actually the stake of the procedure initiated by the seaman René Hablot, since it had no other goal but to add to the 'tab' the debts contracted with the innkeeper L'herbourg, so that the burden would fall upon all his partners. ${ }^{24}$ The crew's 'tab', functioning as an institution within Dieppe's fishing world, has to my knowledge never been mentioned in any other fishing community. It would therefore be interesting to carry out other targeted investigations into the archival funds of several other maritime jurisdictions - in France and elsewhere - in order to assess to what extent this practice prevailed, or whether similar forms existed. Moreover, such a research project would benefit from being extended to a great variety of professional worlds, with a view to studying the whole range of these informal labour institutions, whose specificity was that they were

${ }^{18} \mathrm{AMD}, \mathrm{EE} / 8$ ter, Dossiers de procédures, 15/03/1735.

19 The archive of Vasse the merchant represents in total 41 boxes and registers held at the Archives départementales de Seine-Maritime, Rouen (henceforth ADSM), under the following references: 219/BP/650691.

${ }^{20}$ This is therefore one of the two basic forms of 'business dining' identified by par Beat Kümin, 'Eating Out in Early Modern Europe', in Beat Kümin, ed., A cultural history of food. 4. In the Early Modern Age (London and New York, 2012), 91-92.

${ }^{21}$ Given the recurrence of such cases, it would appear that inns performed the role of a hospital for ill or injured stallholders. Thus, in 1785, Modeste Bertin from Saint-Valéry-en-Caux 'fell unconscious and in such a loss of blood' after being hit on the leg, that his crew members were forced to carry him to the inn kept by Boyard, at the docks (ADSM, 214/BP/113, Dossiers de procédures, 12/12/1785). As for Thomas Caron, who was mauled on board his boat, he was eventually 'carried over to the establishment of dame Hébert, an innkepper in Haut-Pavé, in the parish of Saint Jacques, to be treated and bandaged as befitted his condition'. (ADSM, 214/BP/140, Dossiers de procédures, 18/09/1750).

${ }^{22}$ ADSM, 214/BP/105, Dossiers de procédures, 04/02/1774.

${ }^{23}$ Nonetheless, the special bond created between a crew and an innkeeper did not prevent fishermen from patronising other public houses, in particular the many cabarets located near the harbour.

${ }^{24}$ Regarding the alehouse owners' involvement in 'urban financial microcircuits,' see the book by Laurence Fontaine, L'économie morale. Pauvreté, crédit et confiance dans l'Europe préindustrielle (Paris, 2008), 102-104. 
added on to the public house's own functioning. From this perspective, it is tempting to draw a comparison at this stage with what journeymen called their 'mother' in the same period, referring to both the stopover-hostel where they stayed during their training journey and its publican, which might be a man as well as a woman, but with whom they had a relationship which usually went beyond the basic owner-and-customer relationship. ${ }^{25}$

The bonds between fishermen and the innkeeper where their 'tab' was based are hard to determine because when they transpire through judicial archives, it is always in the context of a dispute. While this makes it possible to detect the tensions - arising through repeated failures to get out of debts that have remained unpaid for too long -, relations of familiarity or even friendship, on the contrary, are elusive. And yet, there is no doubt that they were the bedrock of these associations, as suggested by the reproaches addressed by boat master David Clémence to publican Jean-Baptiste Guilbeaux and his mother in law, the widow Turbé. Both were summoned as witnesses in a suit filed against Clémence by Master Jean-Baptiste Lancel following the 1787 herring season. In his defence statement, indeed, Clémence implies that 'interests and bonds may have led the aforementioned Guilbault and the aforementioned Turbé [...] to testify favourably in favour of the aforementioned Lancel since he and his crew have been keeping and still keep their 'tab' at Guilbault's'. ${ }^{26}$

Some establishments also functioned as shops specialising in the wholesale of alcohol, mainly cider, but also beer and pear brandy. Indeed, there does not seem to be any clear frontier between publicans and shop-owners, and many inns or alehouses also doubled up as shops. Thus, many owners of public establishments took part on supplying boats fitted out for fishing. In particular, they provided casks of alcohol which every crew took to sea. In 1769, the innkeeper Le Borgne, who had a shop on the HautPavé quay, took Félix Bisbeaux into the Admiralty Court: he demanded the sum of 258 livres for 'supplying the aforementioned Bisbeaux and his crew with beverages', between 9 March and 2 September of that same year. ${ }^{27}$ The following year, he started a procedure against Nicolas Duquesne, another master from Le Pollet, in order to have him:

'pay the sum of three hundred and twenty-four livres and nine deniers for the provision of beverages to him and his crew, of which the last delivery was made during Holy week in the year one thousand seven hundred and sixty-nine, of which sum said sir le Borgne has given a label to sir Flouest son, under whose 'hôtage' the boat led by the aforementioned Duquesne is'. ${ }^{28}$

And in fact, some publicans not only sold alcohol in bulk, but also organised the delivery and loaded the goods onto the ships. This is what emerges from the adjudication of a case involving alehouse owner Bayard, over the quote he provided to the merchant Charles Mutel for supplying his ship for the autumn 1785 herring season. ${ }^{29}$ The case of Robert Guiche discussed above is even more interesting, because his dual status as an innkeeper and master cooper led him to develop very tight

\footnotetext{
${ }^{25}$ As far as companionship is concerned, see Émile Coornaert's classic study, Les compagnonnages en France, du Moyen Âge à nos jours (Paris, 1966); and the book by Cynthia M. Truant, The Rites of Labor. Brotherhood of Compagnonnage in Old and New Regime France (Ithaca and London, 1994). A great wealth of information regarding the role of inns in the Old Regime worlds of labour can also be found by reading the glazier companion Ménétra, whose testimony was edited by Daniel Roche, ed., Journal de ma vie. Jacques-Louis Ménétra, compagnon vitrier au XVIII' siècle (Paris, 1982).

${ }^{26}$ ADSM, 214/BP/149, Dossiers de procédures, 20/06/1788. My emphasis.

${ }^{27}$ ADSM, 214/BP/145, Dossiers de procédures, 11/11/1769.

${ }^{28}$ ADSM, 214/BP/146, Dossiers de procédures, 15/05/1770. The 'labels' ('étiquettes') refer to the invoices made by ship suppliers to record deliveries and their amounts.

${ }^{29}$ ADSM, 214/BP/114, Dossiers de procédures, 03/03/1786. The disagreement bore quite specifically on the duration of the fitting out process, as the merchant Mutel complained about the lack of 'velocity' with which Bayard had set about it.
} 
links with the fishing supply sector. He supplied barrels used for the preservation of salted fish and, as discussed above, he used to host in his establishment the 'tab' of the crew led by Augustin Fréchon. However, reading the evidence from the 1735 court case between Master Fréchon and Robert Guiche, it appears that Guiche also had a direct stake in the fishing venture set up between Augustin Fréchon, his seamen and his ship owner, the merchant Du Cattel. The innkeeper, who owned nets, had indeed provided several lots of 'seines' during the previous herring season, which 'helped make the aforementioned catch with a seaman in charge,' thus entitling him to a share of the profits of the society set up under the share system. ${ }^{30}$

Lastly, there were close links in the later stages of the production process, between some of the port's public houses and the sale and transportation sectors for the fish offloaded in Dieppe. ${ }^{31}$ Nicolas Bretel, the owner of an alehouse based on the docks, was therefore the 'écoreur' (i.e. seller) for several fishing boats and, as such, worked as an intermediary between the master and his ship-owner, on the one hand, and the buyers, on the other. He was in charge of delivering the shipments negotiated by these different stakeholders, and also offered use of his warehouses to several local wholesale fish merchants. ${ }^{32}$ Similarly, it is known that some establishments functioned as a stopping point for fair stallholders 'hunting' the fish offloaded in the port towards the inside of the country. ${ }^{33}$ This was the case, among others, of the inns run in the 1770 s by Louis Anquetil and Antoine Houcholle who, when summoned to the Admiralty Court, both introduced themselves as mere 'innkeeper-sellers'. However, reading their depositions, one finds that they went together to 'the hall where assemblies for the sale of mackerel are normally held', not in order to buy some, but 'to provide carriages to the travellers lodging with them'.$^{34}$ Far from being mere meeting points for 'catch-hunters' on the move, the inns run by these two individuals thus appear as actual sub-contracting platforms, at the interface between the local fish market and its distribution networks.

\section{Public Houses as Social Hubs}

Beyond the economic links woven around the public house by money, goods and fish, it is also important to consider the ordinary uses of this institution. Why did fishermen meet at the alehouse? In order to drink, of course, and to find pleasure, strength, solace, escape in alcohol, or just to indulge a fondness for 'stimulants' widespread among sea people, whose alcoholism is well known yet understudied by historians. ${ }^{35}$ Nonetheless, all these explanations do not fully account for the fishermen's assiduous presence at the alehouse - far from it. After all, they could just as easily consume alcohol at home - and certainly did not refrain from doing so, as evidenced by the recurring testimonies starting with the formulation 'I was drinking' at so and so's house. At the risk of

\footnotetext{
${ }^{30}$ AMD, EE/8ter, Dossiers de procédures, 15/03/1735.

${ }^{31}$ These trading functions have already been highlighted in other contexts, notably by Everitt, 'The English Urban Inn', 105-109; or James R. Brown, 'The Landscape of Drink', 148-160.

32 ADSM, 214/BP/140, Dossiers de procédures, 26/06/1750. Many public establishments offered their clients storage spaces, according to Kümin and Tlusty, 'Introduction', 8.

${ }^{33}$ Regarding the distribution networks of sea products and more specifically the role of 'catch-hunters' ('chassemarées'), see Reynald Abad, Le grand marché. L'approvisionnement alimentaire de Paris sous l'Ancien Régime (Paris, 2002), 418-435; Éric Barre, Élisabeth Ridel et André Zysberg, eds., Les nourritures de la mer, de la criée à l'assiette. Techniques de conservation, commerce et pratiques alimentaires des produits de la mer, de l'Antiquité à nos jours (Caen, 2007).

${ }^{34}$ ADSM, 214/BP/106, Dossiers de procédures, 05/07/1775.

${ }^{35}$ Fernand Braudel, Civilisation matérielle, économie et capitalisme. XVe-XVIII siècle. 1. Les structures du quotidien (Paris, 1979), 256-280. For an approach connecting alcohol consumption by fishermen with the problem of the hierarchies internal to their craft community, see Adrian Peace, 'Fishing, Drinking and the Construction of Identity in Rural Ireland', Maritime Anthropological Studies, 4, No. 2 (1991), 3-15.
} 
understating the part played by the culture of 'drinking together', it is important to insist on several socioeconomic practices prevailing in Dieppe's public houses in the eighteenth century, because they make it possible to explain why the actors from the fishing world needed to patronise these institutions. These institutions, which were 'means to an end', starting with the alehouse, did perform locally the role of social hubs where the labour relations internal to the trade community were structured. ${ }^{36}$ Indeed, it was at the alehouse that masters and seamen met when they were not at sea, mingling with a large population of small shopkeepers, craftsmen, labour hands who, like them, sat down to have a drink and engage in discussion. One testimony, Thomas Jacques, a 20-year-old seaman from le Pollet, conveys the atmosphere effectively:

'On the first day of this year, around 8 in the evening, having entered the Brandon alehouse in Le Pollet with his brother in order to have a bottle of cider, they sat down at the end of a table and, there, were sat next to said Robin L'Homme, a seaman living in Bracquemont, being from the crew of Levieux [...], and at the other end of the table sat said Nicolas and Jacques Lameille [...]' ${ }^{37}$

Around these big shared tables, the discussion largely revolved around fishing and its yield. There were comments about the weather, the reasons for an abundance or a shortage of fish; why some were lucky and others weren't; much abuse was hurled - and very conspicuously so - and much fun was had, without a doubt. Reputations were made through these discussions. It was at the alehouse, indeed, the people and things' good or bad reputations were made and unmade. Thus, Pierre jean Dupuis, 22, a seaman from Le Pollet, gave a witness statement in court in which he claimed that 'one evening after the herring season, being on his own at said Tisson's, an alehouse at the dock, to have his share in a denier's worth of cider, he heard François Ville, a seaman from the crew led by David Clémence, say that the aforementioned Clémence was a beast because he had put out his nests without any floaters' ${ }^{38}$ And in fact, rumours and gossip were not confined to men, and extended to boats. Jacques Mauger, dissatisfied with his new boat, which he considered too large and unfit for fishing during wartimes, complained to his owner, Louis Flouest, who retorted:

'Why, if you are that scared, you should quit and go back to your little boat rather than expose this new one to being brought into disrepute in public, which will prevent me from letting it go out to sea. ${ }^{39}$

'Revolving doors of news, rumor and gossip', the public houses of Dieppe's port were therefore as many public spaces where the internal hierarchies of the local fishing world came into place..$^{40}$ The institution of the alehouse, which was the laboratory of reputations, played a major part in the making of crews and fishing supply associations. It was there indeed that a master looking for nets, seamen or a ship to command, came to collect information. In other words, patronising an alehouse presided over agreements, because it allowed access to information about possible transactions.

On that point, the judicial inquiry initiated at the request of Charles Bourdon in July 1749, in order to prove that the merchant Nicolas Jean had really promised to give him the commandment of a new ship, proved decisive. Master Pierre Leblond, summoned to testify, first mentioned remembering 'a drink of wine' which he had had six months earlier with Charles Bourdon. Upon this occasion, in an alehouse in Le Haut-Pavé, the latter had indeed talked about leading a boat under Nicolas Jean's 'hôtage', but in vague terms. However, Pierre Leblond remembered clearly 'hearing him [...] saying

\footnotetext{
${ }^{36}$ Kümin, Drinking Matters, 4.

${ }^{37}$ ADSM, 214/BP/114, Dossiers de procédures, 03/02/1774.

${ }^{38}$ ADSM, 214/BP/149, Dossiers de procédures, 05/05/1788.

${ }^{39}$ ADSM, 214/BP/114, Dossiers de procédures, 04/04/1786.

${ }^{40}$ Adam Fox, Oral and Literate Culture in England, 1500-1700 (Oxford \& New York, 2000), 352-353.
} 
since then in alehouses [...] that he was to command one of Sir Jean's boats'. Indeed, in the hope of commanding this boat as early as the mackerel season in 1749, Charles Bourdon attended assiduously the port's public establishments at the beginning of that year, looking for seamen who might join his crew. Barthélemy Lachelier, for instance, told of how he had been approached by him in January 1748 , while he was drinking 'a quarter gallon of cider' with his brother, at Clémence's, an alehouse on the docks. Walking past his table, Charles Bourdon 'stopped in front of them, had a drink and said, in those terms, that there was going to be much work and he would be very happy if the deponent, who had been with him for two years during the war, would go back under his command, as he was happy with him'. Around the same period, he had made similar propositions in the alehouse of said Flouest, located by the gate of Le Pollet; and at Le Sueur's, 'close to Carmes abbey' where, having met the alehouse owner Nicolas Clémence and his wife, he had come in to have a 'denier of wine' with them 'while waiting for mass to be finished' ${ }^{41}$

Through this example it is possible to observe that patronising the establishments of the port was central to the formation of fishing associations. Men went to the alehouse in order to collect information, with a view to coming to an agreement. Jacques Flament, a shipwright and structure contractor, remembered clearly, in front of the judge, that while he was sitting in Pallissard's alehouse with Master Simon L'heureux and his seaman Jacques Feuillet, both started 'talking nets', and Jacques Feuillet 'promised to said L'heureux that he would provide him with some if he found any for herring fishing' ${ }^{42}$ In Dieppe as elsewhere in Europe in the Old Regime, the public house was a key place for deal-making, for a number of reasons. This role came from the fact, first, that it was a meeting point, where, as described here, people would come to seek economic information, about the rate of goods, good deals, vacancies to fill, etc. Moreover, it would seem that some publicans were active intermediaries. Thus for instance with the alehouse owner Charles Louis Bouquet, approached by the seaman Jean-Baptiste Capelle in early October 1763, asking him to put him in touch with master Jacques Reine. Having both walked up to the latter, all three finally entered 'the alehouse of Burette', where an agreement was finally concluded. ${ }^{43}$ Moreover, and in an even more essential way, this function can be explained through the public nature of the alehouse's communal room. As discovered on reading numerous procedure records, the act of sharing a drink - in other words, to toast - could take special significance in certain circumstances. Invested with a strong symbolical function in Dieppe's fishing world, drinking together became a contractual ritual as soon as it was paired with a word given in public, which it sealed. ${ }^{44}$ Aiming to have Pierre Lefebvre legally forced to return to his crew, Guillaume Legrain thus invoked the 'verbal promise' which, as customary, the seaman 'made to him in the presence of witnesses, having to this effect drunk the wine of his commitment'. ${ }^{45}$ The reason why a seaman's commitment was never accompanied by a written convention is quite simply that it was a public contract, whose binding power and dispositions were guaranteed by the alehouse's acceptance. The public house's public nature gave it a special dimension, of a jurisdictional nature. In some respects this institution was akin to a solicitor's office or a tribunal: indeed, it performed similar functions, insofar as it contributed in the same way to reducing the degree of uncertainty bearing

\footnotetext{
${ }^{41}$ ADSM, 214/BP/149, Dossiers de procédures, 09/07/1749.

${ }^{42}$ ADSM, 214/BP/144, Dossiers de procédures, 15/09/1763.

${ }^{43}$ ADSM, 214/BP/144, Dossiers de procédures, 05/10/1763. This is another instance where the comparison with companionship proves relevant. See Michael Sonenscher, 'Journeymen's Migrations and Workshop Organization in Eighteenth-Century France', in Steven L. Kaplan and Cynthia J. Koepp, eds., Work in France. Representations, Meaning, Organization, and Practice (Ithaca and London, 1986), 74-96, esp. 88-92.

${ }^{44}$ This was a widespread practice according to Beat Kümin, 'Public Houses and their Patrons in Early Modern Europe,' in Kümin and Tlusty, The World of the Tavern, 48. See also Martyn J. Powell, 'Political Toasting in Eighteenth-Century Ireland', History, 91, No. 4 (2006), 508-529.

${ }^{45}$ AMD, EE/8ter, Dossiers de procédures, 22/05/1734. My emphasis.
} 
upon some transactions and to instilling, so to speak, some trust into relationships formed between people. In this respect, it was part of a topography of local transactions, and the archives of civil procedures brought to the Admiralty Court make it possible to identify some of its polarities.

There is no doubt that the docks occupied an important place in this topography. There were spaces of life, work, passage, and were characterised by intense circulation and effective social diversity. It was there that merchants rubbed shoulders with masters and their seamen and came to oversee the hod carriers unloading the fish from their ships, met their colleagues and made arrangements with the harbour master. Men and women from the bourgeoisie, the working classes, sea- and landworkers, labour hands and craft workers... - everyone gravitated around the port, making its surroundings a special meeting place for the entire community. ${ }^{46}$ However, while such encounters provided opportunities to talk shop and start dealings in public, the docks did not appear to be the place to seal formal commitments. In brief, it was the place to start negotiations which were materialised elsewhere.

For indeed, the docks did not give private transactions the same quality of publicity as the alehouse's enclosed space. This particular type of publicity, specific to this institution, very much derived from the power of certification with which publicans were endowed. By remembering the oral contracts made in their establishment, as well as the witnesses present at the time-normally in small numbers, which made it easier to cross-check testimonies - they guaranteed all stakeholders the possibility of successfully resorting to a court in the event of a dispute. And logically, the alehouse owner and his wife were always called upon to corroborate the statements made by the litigants as soon as an investigation was linked to an agreement made in their presence ${ }^{47}$. The ability to attest thus attributed to the managers of public establishments even encouraged social actors to come to the alehouse in other to look for an agreement, to try and find a common ground without incurring major costs, while knowing should it prove necessary that there would always be a 'recording' of the composition attempt to present to a judge. ${ }^{48}$

However, public houses were not the only transaction sites in the fishing world - far from it. Forays into the harbour's notarial archives suggest that in Dieppe, in the first half of the eighteenth century,

\footnotetext{
${ }^{46}$ Georges Lebas, Histoire d'un port normand sous la Révolution et l'Empire. Dieppe. Vingt années de guerres maritimes. Les corsaires de la Manche. La pêche (Dieppe, 1912), 46-50.

47 In another perspective, recent research examining the role played by inns and alehouses with respect to surveillance and social control have also highlighted the certification power assigned to publicans in Old Regime societies. On this point, see Susanne Rau and Olivier Zeller, 'Police des voyageurs et hospitalité urbaine à Lyon à la fin du XVII siècle', in Albrecht Burkardt, Gilles Bertrand and Yves Krumenacker, eds, Commerce, voyage et expérience religieuse. XVI -XVIII' siècles (Rennes, 2007), 113-143; James R. Brown, 'Drinking Houses and the Politics of Surveillance in Pre-Industrial Southampton', in Beat Kümin, ed., Political Space in Pre-industrial Europe (Farnham and Burlington, 2009), 61-80, esp. 63-64; as well as Simona Cerutti's comments pertaining to this historiographic emphasis " Who is below ?" E. P. Thompson, historien des sociétés modernes : une relecture', Annales. Histoire, Sciences Sociales, 70, No 4, 931-956, esp. 941-944.

48 See for instance the testimony of the Turbé widow in ADSM, 214/BP/149, Dossiers de procédures, 08/05/1788: 'Testify that during the last Lent, said David Clémence and Jean-Baptiste Lancel [...] were at his sonin-law Guilbeaux's, an alehouse owner. The aforementioned Lancel told Clémence: can you prove that it was me who cut your nets, to which he was answered by the aforementioned Clémence that he could not. So why are you attacking me if you cannot do it? What if I paid for the damage, would you give me a slip in which you would accept that you cannot prove that it was I who cut you? Clémence said yes; but if this is so, Lancel continued, why do you expose me to passing off as a man capable of causing someone prejudice, and at the same time inflicting upon my crew some losses which they have not caused? Clémence replied: the reason why I am attacking you is because I saw you first about me, and it is better to paid for damage in common rather than just one losing all his money [...]'.
} 
church squares might perform similar functions. Indeed, 'so that no one may ignore it', the locality's notaries would publicly announce, after Sunday mass, the written contracts passed before them during the week, and then have them signed by witnesses chosen among the parishioners. ${ }^{49}$ Lastly, of course, modern civil courts were led to see to requests on the part of litigants which go beyond dispute resolution, having to do with the certification of rights and contracts. ${ }^{50}$ And indeed, the Admiralty court represented one of the major pole in the local topography of transactions, even if social actors tended to turn to it as a last resort, following a profound disagreement regarding the value of a debt or the binding nature of a commitment, for instance..$^{51}$

One major conclusion to be drawn from the overview of civil procedures involving innkeepers and alehouse owners in cases connected with the fishing world is that this is certainly a very fertile and fairly uncharted topic of research, which, through closer scrutiny of local archives, could be explored in a more in-depth way. In fact, even though they are extremely rich in terms of contents, the sources used in this article mainly shed light on the economic and professional uses of public houses, but still leave many other aspects unexplored. This with the place and role of women, for instance: while the archives hint at their presence both behind the counter and among the alehouses' patrons, it remains difficult to form a definite judgment regarding their actual presence in these institutions. ${ }^{52}$ Similarly, many ritual uses of public houses which were quite widespread in Old regime societies are never mentioned in judicial sources, such as christenings, weddings, or simply modern celebrations in their many guises. ${ }^{53}$ Nonetheless, approaching inns and alehouses from the perspective of civil litigation makes it possible to highlight some practices left relatively unexamined by other types of sources. Thus many converging clues already suggest that there existed in Dieppe highly specialised institutions, which had relations of interdependence with maritime activities, which were even closer than those evidenced by works of history dealing with littoral societies. Public houses were spaces of life and passage, transactions and exchange (of goods as well as information), which seemed to operate in perfect interaction with the local fishing world. The best proof of this is undoubtedly the habit of fishing crews of 'having their tab' in one of the port's inns. However, public establishments performed many other functions which were vital to the smooth operation of maritime activities. Indeed, delineating the many polarities of a local fishing arena, alehouses were part of fundamental social and professional processes, such as the construction (or destruction) of the reputation of craftsmen, the circulation of information and the making of fishing associations. It must be said finally that the public character specific to these semi-public spaces, along with the power of certification implicitly granted to their publicans, made them key sites for the production of trust, in a world of labour characterised by a uniquely high degree of risk and uncertainty.

\section{Translated by Constance Bantman}

\footnotetext{
${ }^{49}$ ADSM, 2E/36/83-193, Étude de Jacques Grandcamp, 1710-1747.

50 Renata Ago, 'Rome au XVII siècle : un marché baroque', Genèses, 50, No 1, 2003, 4-23; Simona Cerutti, Étrangers. Étude d'une condition d'incertitude dans une société d'Ancien Régime (Montrouge, 2012), esp. 247248.

51 The social uses of justice specific to actors from Dieppe's fishing world are analysed in Romain Grancher, 'Les usages de la mer', 117-148.

${ }^{52}$ For a gendered approach to public houses, see Beat KüMIN, 'Public Houses and their Patrons in Early Modern Europe', 55-60.

${ }^{53}$ On this topic, see for instance Angela McShane, 'Material Culture and "Political Drinking" in SeventeenthCentury England"', Past and Present, Supplement 9, 2014, 247-276.
} 